\title{
Effect of DDS therapy on blood pyruvate and lactate levels in leprosy patients
}

\author{
VP BHARADWAJ, V SRITHARAN, K VENKATESAN, \\ G RAMU \& KV DESIKAN \\ Central JALMA Institute for Leprosy, Taj Ganj, Agra-282001, \\ India
}

Received for publication 2 September 1979

\begin{abstract}
Summary A study was undertaken with an aim to find out if DDS could have any effect on the thiamine levels of leprosy patients. Cases of lepromatous leprosy with and without neuritis were the subjects of this study. Pyruvate tolerance test was done in the blood of these patients before and after DDS treatment; blood pyruvate and lactate estimations were done. LL with neuritis gave significantly decreased pyruvate tolerance and the lactate/pyruvate ratio was significantly less than the controls and lepromatous patients without neuritis. This may be indicative of a subnormal status of thiamine in these patients. DDS treatment of these cases resulted in further enhancement of pyruvate values, probably indicating a progressive thiamine deficiency. Those patients who were on prolonged treatment, however, showed near normal values. It is suggested that DDS may cause derangement in pyruvate and lactate metabolism, which however needs further work to understand the underlying mechanism of this phenomenon.
\end{abstract}

\section{Introduction}

Dapsone is widely used in the treatment of leprosy, malaria prophylaxis as well as in certain chronic dermatologic disorders (Lorincz and Pearson, 1962). ${ }^{1} \mathrm{~A}$ rare complication of Dapsone therapy in skin disorders is peripheral neuropathy (Saqueton, 1969:2 Hubler and Soloman, 1972; ${ }^{3}$ Rapport, 1972;4 Wyatt, 1972; Duviviera, 1974;6 Gutman, 1976; $;^{7}$ Fredericks, 1976; Epstein and Bohm, 1976). ${ }^{9}$ Neuritis is not uncommon in lepromatous leprosy. The thiamine deficiency affects predominently the peripheral nervous system and at the same time thiamine is of value in treating various types of neuritis (Harper, 1977). ${ }^{10}$ Our interest was drawn to find out if the neuritis encountered in leprosy patients after DDS therapy was due to a drug induced deficiency of 
thiamine or not. A pyruvate tolerance test was conducted and blood pyruvate and lactate levels were estimated.

\section{Materials and methods}

Forty-four leprosy patients were selected and grouped as follows:

(i) Eighteen untreated lepromatous patients without neuritis.

(ii) Ten lepromatous patients with neuritis.

(iii) Sixteen patients who were on prolonged treatment and

(iv) Twelve healthy volunteers formed the controls.

A pyruvate tolerance test was done on each patient by administering $50 \mathrm{gm}$ of glucose orally and collecting the blood samples $1 \mathrm{hr}$, and $3 \mathrm{hrs}$ after administration. All untreated cases of leprosy were put on $100 \mathrm{mg}$ DDS daily for complete four days and the pyruvate tolerance test was repeated. A period of four days was chosen for DDS therapy arbitrarily.

Pyruvate was estimated by the method of Friedman and Haugen (1943) ${ }^{11}$ and lactate by the method of Barker and Summerson $(1941)^{12}$ cited in Varley (1976). ${ }^{12}$

\section{Results}

It was found in normal healthy persons that ingestion of glucose was followed by a short but steep elevation of blood pyruvate and lactic acids which reached a maximum in $1 \mathrm{hr}$ and returned to basal level after $3 \mathrm{hrs}$. The ratio of lactate/ pyruvate remained constant throughout and it was around 10 .

Significant increase $(p<0.01)$ in the basal value of pyruvate was noted in untreated LL cases with neuritis and the pyruvate tolerance was significantly decreased. After treatment there was a slight increase in basal and first hour samples $(p>0.05)$. The mean lactate values after treatment were higher than the control values and than those before treatment with DDS. The ratio of lactate/pyruvate for the tolerance test ranged between 3-9 before treatment and between $5-8$ after treatment.

The untreated LL cases showed nearly similar results although their tolerance was higher than the neuritis group. Lactate/pyruvate ratio ranged between 6-10 in these cases. After treatment with DDS, their tolerance decreased further, the ratio of lactate/pyruvate being $8-15$.

The patients on prolonged treatment with DDS presented average higher values compared to controls, their lactate/pyruvate being higher than the untreated LL cases, within a range of $8-11$. The results of our present study are presented in Table 1 . 
Table 1.

\begin{tabular}{|c|c|c|c|c|c|}
\hline Materials & $\begin{array}{l}\text { No of } \\
\text { cases }\end{array}$ & $\begin{array}{c}\text { Blood samples } \\
\text { studied }\end{array}$ & $\begin{array}{c}\text { Blood pyruvate } \\
\text { mg\%* }\end{array}$ & $\begin{array}{l}\text { Blood lactate } \\
\mathrm{mg} \%\end{array}$ & Lactate/Pyruvate \\
\hline $\begin{array}{l}\text { 1. Normal control } \\
\text { subjects }\end{array}$ & 12 & $\begin{array}{l}\quad \text { Basal } \\
1 \mathrm{hr} \\
3 \mathrm{hrs}\end{array}$ & $\begin{array}{l}0.76 \pm 0.08 \\
0.92 \pm 0.17 \\
0.74 \pm 0.10\end{array}$ & $\begin{array}{r}7.8 \pm 0.63 \\
9.62 \pm 0.34 \\
7.83 \pm 0.48\end{array}$ & $\begin{array}{l}10.26 \\
10.456 \\
10.581\end{array}$ \\
\hline $\begin{array}{l}\text { 2. LL with neuritis- } \\
\text { untreated cases } \\
\dagger(p<0.01)\end{array}$ & 10 & $\begin{array}{l}\text { Basal } \\
1 \mathrm{hr} \\
3 \mathrm{hrs}\end{array}$ & $\begin{aligned} 1.963 & \pm 0.216 \\
2.413 & \pm 0.41 \\
1.6509 & \pm 0.34\end{aligned}$ & $\begin{array}{r}7.52 \pm 0.36 \\
7.85 \pm 0.64 \\
14.97 \pm 0.50\end{array}$ & $\begin{array}{l}3.836 \\
3.252 \\
9.067\end{array}$ \\
\hline $\begin{array}{l}\text { After treatment with } \\
\text { DDS } 100 \mathrm{mg} \text { for } 4 \text { days } \\
\dagger_{(\mathrm{p}>0.01)}\end{array}$ & & $\begin{array}{l}\quad \text { Basal } \\
1 \mathrm{hr} \\
3 \mathrm{hrs}\end{array}$ & $\begin{aligned} 1.974 & \pm 0.373 \\
2.79 & \pm 0.193 \\
1.836 & \pm 0.93\end{aligned}$ & $\begin{array}{r}12.13 \pm 0.38 \\
14.0 \pm 0.38 \\
15.57 \pm 0.37\end{array}$ & $\begin{array}{l}6.145 \\
5.018 \\
8.480\end{array}$ \\
\hline $\begin{array}{l}\text { 3. L L untreated } \\
\dagger(p>0.05)\end{array}$ & 18 & $\begin{array}{l}\quad \text { Basal } \\
1 \mathrm{hr} \\
3 \mathrm{hrs}\end{array}$ & $\begin{array}{l}1.856 \pm 0.468 \\
1.985 \pm 0.532 \\
1.474 \pm 0.7642\end{array}$ & $\begin{array}{r}12.684 \pm 6.9 \\
15.75 \pm 1.09 \\
15.297 \pm 0.75\end{array}$ & $\begin{array}{r}6.834 \\
7.935 \\
10.338\end{array}$ \\
\hline $\begin{array}{l}\text { After treatment with } \\
\text { DDS } 100 \mathrm{mg} \text { for } 4 \text { days } \\
t_{(\mathrm{p}>0.05)}\end{array}$ & & $\begin{array}{l}\text { Basal } \\
1 \mathrm{hr} \\
3 \mathrm{hrs}\end{array}$ & $\begin{array}{l}2.563 \pm 0.179 \\
2.652 \pm 0.072 \\
1.530 \pm 0.026\end{array}$ & $\begin{aligned} 23.4 & \pm 0.6 \\
21.22 & \pm 0.65 \\
23.183 & \pm 0.18\end{aligned}$ & $\begin{array}{r}9.129 \\
8.000 \\
15.152\end{array}$ \\
\hline $\begin{array}{l}\text { 4. LL on prolonged treatment } \\
\dagger(p>0.05)\end{array}$ & 16 & $\begin{array}{l}\quad \text { Basal } \\
1 \mathrm{hr} \\
3 \mathrm{hrs}\end{array}$ & $\begin{array}{l}1.313 \pm 0.62 \\
1.959 \pm 1.05 \\
1.549 \pm 0.53\end{array}$ & $\begin{array}{r}12.925 \pm 0.5 \\
15.718 \pm 0.53 \\
17.26 \pm 0.46\end{array}$ & $\begin{array}{r}9.844 \\
8.023 \\
11.146\end{array}$ \\
\hline
\end{tabular}

${ }^{*} \mathrm{SD}$

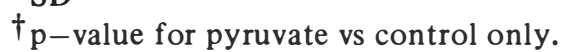




\section{Discussion}

Thiamine deficiency results in a form of peripheral neuritis affecting both the sensory and motor nerves. Dapsone has been reported to induce (peripheral) neuropathy, principally of motor type, and recovery was assured if DDS therapy was withdrawn (Williams and Bradley, 1972). ${ }^{13}$ The reason why some individuals develop neuropathy after DDS therapy is not certain. The period for the development of neuropathy is quite variable. They have used larger doses of DDS and it has been suggested that the neurotoxicity of DDS is dose dependent. Even higher doses of DDS failed to induce neuropathy in guinea-pigs and rats (Williams and Bradley, 1972) ${ }^{13}$ which shows that this neurotoxicity of DDS is genetically determined. Gutman $(1976)^{7}$ suggests that the neurotoxicity is related to an effect on the axons and said that the recovery occurs after toxic effect might enhance the risk of deformities in leprosy patients. Gelber $(1971)^{15}$ reports that the process of deacetylation of Dapsone was more than acetylation. It leads to the accumulation of free drug (DDS), which being less soluble induces a drug toxicity at the neuronal levels.

Williams and Bradley (1972) ${ }^{13}$ have also reported that the key enzymes of glycolytic pathway (Glucose-6-phosphate dehydrogenase, phosphof ructo kinase, pyruvate kinase, aldolase) were within normal limits which proves that the production of pyruvate is normal but the increased abnormal levels of pyruvate can be explained only if there occurs a disturbance beyond pyruvate production. Our studies show that pyruvate accumulates in much higher quantities than normally it should be which connotes that only the catabolism of pyruvate to acetyl $\mathrm{CoA}$ is depressed. This leads to decreased production of acetyl CoA and is a possible explanation for the decreased rate of acetylation of DDS.

Similar reports are available on the neurotoxicity of INH on tuberculosis patients due to decreased rate of acetylation and hence the elimination of the drug from the blood. The severity of neuropathy is determined both by the rate of acetylation and the total dose given ( $\mathrm{La} \mathrm{Du}, 1972) .{ }^{16}$ In the present study blood pyruvate levels were significantly elevated in untreated cases with and without neuritis when compared to the controls. After treatment with DDS an exaggeration in the pyruvate levels was observed. The pyruvate levels were also higher in LL cases on prolonged treatment but the increase was less than the previous two groups. The increase in pyruvate levels may be suggestive of thiamine deficiency. However $B_{1}$ deficiency is by no means the sole cause of an elevated blood pyruvic acid and the test is not specific unless accompanied by a therapeutic trial demonstrating improvement following administration of thiamine. The increase in blood pyruvate values in almost all the cases after DDS therapy is an interesting finding in our study and is not certain if the reported toxicity of DDS could be mediated through a pyruvate toxicity. This needs further probe. The near normal values obtained 
for patients on prolonged treatment could be easily explained because they were also taking, apart from DDS, B Complex vitamin preparations.

It is possible that DDS affects the normal degradative pathway of pyruvate and so more of pyruvate may be converted to lactate. This abnormality in pyruvate catabolism can not be attributed solely due to a drug-induced deficiency of thiamine alone and it needs further confirmation. A study of transketolase enzyme, blood pentose levels and above all a direct assay of thiamine would throw more light on these findings which would be confirmatory. Investigations of other B vitamins are also envisaged because isolated discrete deficiency of any B vitamin is not very common. They usually reveal symptomatically as a combined deficiency of B vitamins.

A follow up of the cases included in the present study is planned to understand the effect of prolonged treatment with DDS on the thiamine status of these patients.

\section{References}

1 Lorincz AL, Pearson RW. Sulfonamides and sulfone type of drugs in dermatology. Arch Dermatol 1962, 85, 2.

2 Saqueton AC. Dapsone and peripheral motor neuropathy. Arch Dermatol, 1969, 100, 214.

3 Hubler WR, Soloman. Neurotoxicity of sulfones, Arch Dermatol, 1972, 106, 598.

4 Rapport AM. Dapsone induced peripheral neuropathy. Arch Neurol, 1972, 27, 184.

5 Wyatt EH. Dapsone induced peripheral neuropathy. Brit J Dermatol, 1972, 86, 521.

${ }^{6}$ Duviviera. Possible Dapsone induced neuropathy in dermatitis herpeliformis. Proc $R$ Soc Med, 1974, 67, 439.

7 Gutman L. Dapsone motor neuropathy axonal disease. Neurology, 1976, 26, 514.

8 Fredericks ED. Dapsone induced motor polyneuropathy. Arch Dermatol, 1976, $112,1161$.

9 Epstein FW, Bohm M. Dapsone induced peripheral neuropathy. Arch Dermatol, 1976, 112,1158 .

10 Harper Harold A. Review of physiological chemistry, 16th edn; California; Lange Medical Publications, p. 158, 1977.

11 Friedmann TE, Haughen GE, cited by Harold Varley Practical clinical biochemistry, 4th edn, Arnold-Heinemann Publishers (India) Pvt Ltd., 1976, p. 612.

12 Barker SB, Summerson WH. (1941) cited by Harold Varley Practical clinical biochemistry, 4th edn, Arnold-Heinemann Publishers (India) Pvt Ltd., (1976), p. 616.

13 Williams MH, Bradley WG. An assessment of Dapsone toxicity in the guinea pig. Brit J Dermatol 1972 86, 650.

14 Gupte MD Dapsone treatment and deformities - a retrospective study. Lepr India, 1979, 51, 218.

15 Gelber, R. The polymorphic acetylation of dapsone in man, Clin Pharmac Ther, 1971, 12, 225.

$16 \mathrm{La} \mathrm{Du} \mathrm{BN.} \mathrm{Isoniazid} \mathrm{and} \mathrm{pseudocholine} \mathrm{esterase} \mathrm{polymorphism.} \mathrm{Fed} \mathrm{Proc,} \mathrm{1972,} \mathrm{31,}$ 1276. 